\title{
What, if Anything, is Quaternary?
}

\author{
John A. Van Couvering ${ }^{1}$, Marie-Pierre Aubry', William A. Berggren ${ }^{3}$,Felix M.Gradstein ${ }^{4}$, \\ Frits J. Hilgen ${ }^{5}$, Dennis V. Kent ${ }^{6}$, Lucas J. Lourens ${ }^{7}$, and Brian McGowran ${ }^{8}$ \\ 1 The Micropaleontology Project, 256 Fifth Avenue, New York, NY 10001, USA. Email: vanc@micropress.org \\ 2 Earth and Planetary Sciences, Rutgers University, Piscataway, NJ 08854-8066, USA. Email: aubry@ rci.rutgers.edu \\ 3 Woods Hole Oceanographic Institution, Woods Hole, MA 02543, USA. Email: wberggren@whoi.edu \\ 4 University of Oslo, POB 1172 Blindern, N-0318 Oslo, Norway. Email: felix.gradstein@nhm.uio.no \\ 5 Department of Earth Sciences, Utrecht University, Utrecht, Netherlands. Email: fhilgen@ geo.uu.nl \\ 6 Earth and Planetary Sciences, Rutgers University, Piscataway, NJ 08854-8066. Email: USA - dvk@ rci.rutgers.edu \\ 7 Department of Earth Sciences, Utrecht University, Utrecht, Netherlands. Email: 1lourens@geo.uu.nl \\ 8 Earth and Environmental Sciences, University of Adelaide, SA 5005, Australia. Email: brian.mcgowran@adelaide.edu.au
}

The formal recognition of Quaternary as a Period/ System was approved by IUGS in June 2009, in accordance with a proposal originated by INQUA. There are reasons to believe that this will have destabilizing consequences for the geological time scale. Until now, the primary divisions of the stratigraphic record, at the Period level and above, have been based on the progressive change of Earth's biota. The Quaternary, on the other hand, is a paleoclimatic concept based on glacial-interglacial variability, expressed in lithological change. The IUGS vote holds that this paradigm now supersedes the biochronological identity of the Neogene Period/System. Furthermore, to accomodate the most recent INQUA opinion about "when the Ice Ages began", the ICS agreed to relocate the base of the Pleistocene to 2.59 Ma from $1.81 \mathrm{Ma}$, enlarging the epoch by $43 \%$ and again without regard for its original paleontological definition, or for the vast literature in other fields of Pleistocene research. If history is a guide, the resulting disruption in late Cenozoic marine and vertebrate paleontology, human evolution, paleoceanography and paleoclimatology will be widely resisted, with potential impact on the authority of IUGS. The consequence of abandoning basic principles in order to satisfy the interest of a special group deserves a wider consideration than it has so far received.

In May 2009, the International Commission on Stratigraphy (ICS) voted to accept a proposal from INQUA, forwarded by the Subcommission on Quaternary Stratigraphy (SQS), that would formally adopt a Quaternary Period/System in the standard geological time scale. INQUA was reacting to the omission of Quaternary, in any form, from the most recently revised ICS time scale (Gradstein, Ogg and Smith, 2004; Lourens et al. 2004). Its editors and authors had taken the not unreasonable view (see Berggren, 1998; Hilgen et al. 2008) that the "alluvial" Quaternary, despite its climatic significance, was not any more valid as a unit in the modern time scale than the other three stages of lithification (Primary, Secondary and Tertiary) by which Arduino (1760) and other Renaissance philosophers had initially arranged Earth's strata. To rectify this, INQUA proposed to end decades of varied and informal usage by establishing a formal Quaternary Period equivalent to Pleistocene and Holocene - but with its base in the Gelasian GSSP at c. 2.59 Ma, not the Calabrian GSSP at c.1.81 Ma. This was justified explicitly because the older level is coeval with a cold climate cycle that is seen as the beginning of Quaternary climate (Gibbard et al. 2005; Head, Gibbard and Salvador, 2008) - and for no other stated reason.

The IUGS swiftly ratified the ICS vote in June 2009, rejecting without comment a petition submitted on behalf of the American and Russian stratigraphic commissions and co-signed by several former officers of ICS, asking for a delay to consider the consequences of the vote. In so doing, the IUGS invalidated the original, biochronological definition of the Neogene Period/System (Hilgen et al. 2008, and refs therein), the latter part of which covers the same interval. More importantly, by accepting the proposal to enlarge the Pleistocene Series/ Epoch by $43 \%$ with the redesignation of its base in the 2.59-Ma GSSP of the Gelasian Stage at San Nicolà, in order to agree with the $a$ priori paleoclimatic definition of the Quaternary, the IUGS also set aside Lyell's (1833) original paleontological characterization of the epoch. This paleontological criterion was the first priority in the mandate of the 1948 London IGC to establish a physical reference point for the Pleistocene boundary (King and Oakley, 1950), and it guided the years of work by IGCP 41 that finally resulted in the definition of Pleistocene in the 1.81-Ma base of the Calabrian Stage at Vrica (Aguirre and Pasini, 1985; Van Couvering, 1997) - one of the first GSSPs ever adopted.

The ICS voters rejected a counter-proposal to make the Quaternary a Neogene subunit (Lourens, 2008; McGowran et al. 2009), and did not consider other alternatives such as a Cenozoic sub-era (Aubry et al. 2005; Gradstein and Finney, 2007), or a Period/System defined in the Vrica GSSP (S.C. Finney, in litt., 2009). There are, however, major consequences that follow from the proposal that was adopted, that were not brought into the discussion, and that IUGS should properly have considered.

First of all, it was not recognized that the INQUA proposal was in conflict with the fundamental organization of the Phanerozoic time scale, which is divided - and particularly at the level of Period/Ststem and above - according to the progressive change of Earth's biota. From this point of view, there is no end-Cenozoic period, sub-period or sub-era, Quaternary or otherwise, because there is no significant 
change in the fossil record during this time (Aubry et al. 2009). We all know that geological time was first recognized in the systematic observations of marine fossil sequences, but it is not so well understood that no other features of the strata could have served this purpose. It is for this reason that Phanerozoic boundaries continue to be defined according to fossils (almost universally marine) even as chronostratigraphy replaces the old biostratigraphic system (Aubry et al. 2009) and isochronous correlation tools become more relevant in deciding precisely where to locate the physical reference point. Nevertheless, the reason to have a boundary at all is biotic change. It remains the fact that the linear progress of organic evolution is one of only two ordinal systems that span geological time (Berggren and Van Couvering, 1978), the other being radioactive decay, and it is the accessibility and complex meaning of the fossil record that makes paleontology preferable to radiometry in organizing geologic history. Once biotic change becomes the metric, then logic dictates that the measured units be framed in these terms to avoid miscommunication and conflict.

The most recent faunal change that reaches the importance of a period boundary is the emergence of the modern biota during the Oligocene-Miocene transition some $23 \mathrm{Myr}$ ago (Stanley, 2009; Aubry et al. 2009) - which identifies the beginning of the Neogene Period/ System. By contrast, the time ascribed to Quaternary includes no significant biotic event, aside from shifts in the geographic ranges of the Neogene fauna in response to oscillations in climate (Aubry et al. 2009). How, then, can Quaternary be defended as a Period? In a note to ICS chair Finney (M. J. Head et al., in litt., Feb. 2009), the proposers cited as their primary justification (ibid., point 5) that "Users of the geological time scale must be considered, and the Quaternary community numbers 50,000 worldwide with INQUA serving as its voice. INQUA, which has equal status with the IUGS under the International Council of Science (ICSU), unanimously endorses the $S Q S$ proposal." The use of the paleoclimatic criterion was characterized as a "holistic" approach (ibid.), but as the cited justification makes clear, the shift to "holistic" criteria is meant to allow revisions to the the time scale according to the interest of special groups. Jurisdictional and political dispute, in place of regulated consensus, may be expected to follow.

Secondly, in the particular case in question, the new status of Quaternary will impact a vast literature in the Late Cenozoic, not only in marine and continental paleontology but also paleoanthropology, paleoceanography and paleoclimatology. Throughout these subject areas "Pleistocene" is a key concept, whereas "Quaternary" is seldom used. Given the perpetual controversy and and unstable history of the Quaternary (Hilgen et al. 2008), there is a strong probability that the redefinition of the Pleistocene to conform to this latest version of the ice age concept, because of its radically destabilizing effect, will be met with resistance if not outright rejection across a wide range of earth science, with serious implications for the authority of IUGS.

In sum, a Quaternary Period/System cannot be seen in Late Neogene paleofaunas. To impose it according to other criteria would be to abandon the fossil record as the fundamental meter of geological time, and thereby to expose the time scale to conflicting agendas of various interest groups. Secondly, we believe that the adoption of a Quaternary Period that radically distorts the Pleistocene to fit a non-standard model will result in a new and greater conflict rather than the final compromise that has eluded our science for over a century. The profession must now consider how to deal with these possible negative consequences, whether by revisiting and clarifying the guidelines by which time scale boundaries are defined, or by returning once more to the search for a compromise under which the legitimate interests of Quaternary stratigraphers can be peacefully accomodated.

\section{References}

Aguirre, E. and Pasini, G., 1985. The Pliocene-Pleistocene boundary. Episodes, 8, 116-120.

Arduino, G., 1760. Sopra varie sue Osservazioni fatte in diverse parti del Territorio di Vicenza, ed altrove, appartenenti alla Teoria Terrestre, ed alla Mineralogia. [Letter to Prof. Antonio Vallisnieri, dated $30^{\text {th }}$ March 1759]. Nuova Raccolta do Opuscoli Scientifici e Filologici del Padre Abate Angiola Calagierà, 6, 142-143.

Aubry, M.-P., Berggren, W. A., Van Couvering, J. A., McGowran, B., Hilgen, F., Steininger, F. and Lourens, L., 2009. Neogene and Quaternary: chronostratigraphic compromise or non-overlapping magisteria? Stratigraphy, 6, 1-16.

Aubry, M.-P., Berggren, W. A., Van Couvering, J. A., McGowran, B., Pillans, B. and Hilgen, F., 2005. Quaternary: status, rank, definition, survival. Episodes, 28, 118-120.

Berggren, W. A., 1998, The Cenozoic Era: Lyellian (chrono)stratigraphy and nomenclatural reform at the millenium, in Blundell, D. J. and Scott, A. G., eds., Lyell: The past is the key to the present, The Geological Society, London. Special Publication 143. 111-132.

Berggren, W. A. and Van Couvering, J. A., 1978. Biochronology, in Cohee, G. V., Glaessner, M. F. and Hedberg, H. D., eds., Contributions to the Geologic Time Scale, American Association of Petroleum Geologists, Tulsa. Studies in Geology, no. 6, pp. 39-55.

Gibbard, P. L., Smith, A. G., Zalasiewicz, J. A., Barry, T. L., Cantrill, D., Coe, A. L., Cope, J. C. W., Gale, A. S., Gregory, J., Powell, J. H., Rawson, P. F., Stone, P. and Waters, C. N., 2005. What status for the Quaternary? Boreas, 34, 1-6.

Gradstein, F. M. and Finney, S., 2008. On the Ordovician Period and Quaternary Subera. GeoArabia, 12, 205-210.

Gradstein, F. M., Ogg, J. G., and Smith, A. G., eds., 2004. A Geologic Time Scale 2004. Cambridge:.Cambridge University Press, 589p.

Head, M. J., Gibbard, P. L., and Salvador, A., 2008. The Quaternary: its character and definition. Episodes, 31(2), 234-238.

Hilgen, F. J., Aubry, M-P., Berggren, W. A., Van Couvering, J. A., McGowran, B. and Steininger, F., 2008. The case for the original Neogene. Newsletters on Stratigraphy, 43(1), 23-32.

King, W. B. R and Oakley, K. P., 1950. Report of the Temporary Commission on the Plio-Pleistocene Boundary, in: Butler, A. J., ed., International Geological Congress, Report of the Eighteenth Session, Great Britain, 1948. Part 1, Proceedings. The Geological Society, London, pp.213214.

Lourens, L. J., 2008. On the Neogene-Quaternary debate. Episodes, 31, pp. 239-242.

Lourens, L. J., Hilgen, F., Shackleton, N. J., Laskar, J. and Wilson, D., 2004 The Neogene Period, in Gradstein, F. M., Ogg, J. G. and Smith, A. G., eds., 2004. A Geologic Time Scale 2004, Cambridge University Press, Cambridge, pp. 409-440.

Lyell, C., 1833. Principles of geology: being an attempt to explain the former changes in the Earth's surface, by reference to causes now in operation. Volume 3. London: John Murray.

McGowran, B., Berggren, W. A., Hilgen. F., Steininger, F., Aubry, M.-P., Van Couvering, J. A. and Lourens, L., 2009. Neogene and Quaternary coexisting in the geological time scale. the inclusive compromise. Earth Science Reviews, doi:10.1016/j.earscirev.2009.06.006.

Stanley, S. M., 2009. Earth system history, 3rd edition. New York: W.H. Freeman, 551p.

Van Couvering, J. A., 1997. Preface: The new Pleistocene, in Van Couvering, J. A., ed., The Pleistocene boundary and the beginning of the Quaternary. Cambridge University Press, Cambridge, pp. xi-xvii. 